
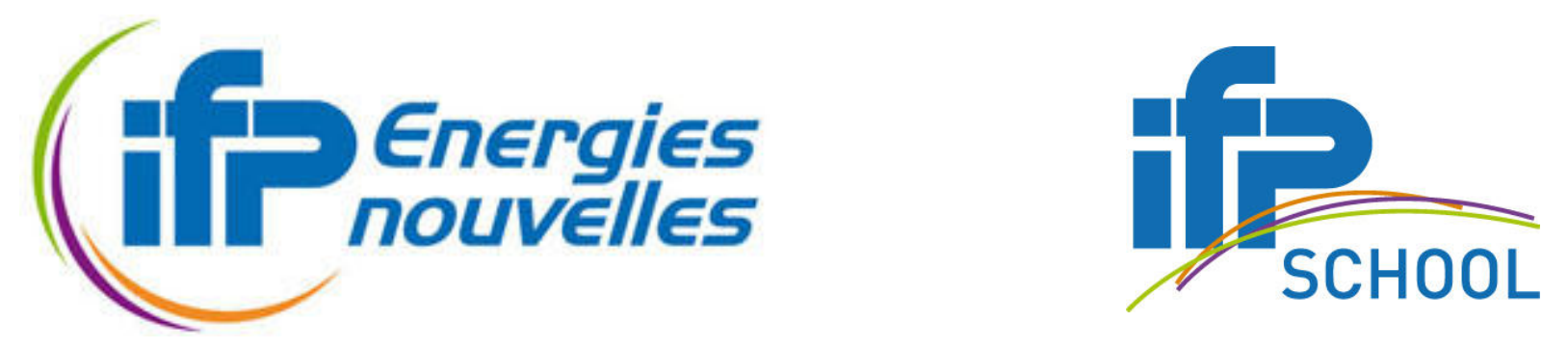

\title{
Do renewable energies improve energy security in the long run?
}

\author{
Emmanuel HACHE
}

Septembre 2016

\section{Les cahiers de l'économie - $n^{\circ} 109$}

\section{Série Recherche}

emmanuel.hache@ifpen.fr

La collection "Les cahiers de l'économie" a pour objectif de présenter des travaux réalisés à IFP Énergies Nouvelles et à IFP School, travaux de recherche ou notes de synthèse en économie, finance et gestion. La forme peut être encore provisoire, afin de susciter des échanges de points de vue sur les sujets abordés. Les opinions émises dans les textes publiés dans cette collection doivent être considérées comme propres à leurs auteurs et ne reflètent pas nécessairement le point de vue d' IFP Énergies Nouvelles ou d' IFP School.

Pour toute information sur le contenu, prière de contacter directement l'auteur.

Pour toute information complémentaire, prière de contacter le Centre Économie et Gestion: Tél +33 147527227

The views expressed in this paper are those of the authors and do not imply endorsement by the IFP Energies Nouvelles or the IFP School. Neither these institutions nor the authors accept any liability for loss or damage incurred as a result of the use of or reliance on the content of this publication. 



\title{
Do renewable energies improve energy security in the long run?
}

\author{
Emmanuel Hache ${ }^{123}$
}

\begin{abstract}
:
The aim of this article is to analyze the geopolitical consequences of the spread of renewable energies worldwide. From a macroeconomic point of view, it would be tempting to conclude that the transition to renewables (solar, wind...) will gradually end today's geopolitics of fossil fuels based on historical relationships between energy producers and consumers. The new challenges induced by energy transition policies could paradoxically turn out being as complex as today's geopolitics of energy. Local and decentralized relations could add a new geopolitical layer to current traditional actors. Technical, economic, sociological, behavioural, spatial and legal dimensions could also complicate the emerging puzzle. A massive diffusion of renewables into the world's energy mix could also lead to new, unexpected interdependencies such as dependencies to critical materials, a new geopolitics of patents and the implementation of a renewable diplomacy.
\end{abstract}

Keywords: Energy transition, energy security, critical materials, patents, energy technology JEL Classification: Q48, Q58, Q34, O33, O34.

\footnotetext{
${ }^{1}$ IFP Énergies Nouvelles, 1-4 av. de Bois Préau, F-92852 Rueil-Malmaison, France.

${ }^{2}$ The French Institute for International and Strategic Affairs, (IRIS), France.

${ }^{3}$ I'm grateful to Théo Fayolle, Eva Lancelin and Hugo Liagre for insightful comments and suggestions. Of course, any remaining errors are mine. The views expressed herein are strictly those of the authors and are not to be construed as representing those of IFP Énergies Nouvelles or IRIS.
} 
Historically, the highlight on the strategic nature of crude oil has always been associated to World War I. This period remains a true catalyst for the importance to dispose of oil resources and to ensure their securing. Thus was reinforced the idea that the search for energy sources constituted a major diplomacy component. The 1930s and World War II further strengthened this dynamic and made the structuration of international relations possible. Indeed, the 1928 Achnacarry agreement ${ }^{4}$, just like the 1931 Red Line agreement or the 1945 Quincy agreement, brought forward structural elements to the relations between countries consuming and producing oil. Later, in 1960, this "harmony" was ruptured by the creation of the Organization of the Petroleum Exporting Countries (OPEC), which symbolized the idea that the possession of a power source could be used as a political weapon and a power instrument. The OPEC thus unveiled a new face of international relations, one in which the geological geopolitics of certain countries carry a too heavy weight - disproportioned when compared to their population and their gross domestic product (GDP) ${ }^{5}$.

The European construction was especially representative of the impact energy has on interstate relationships. Indeed, it's around this very factor that were structured the first integration attempts, in particular within the European Coal and Steel Community (ECSC), in 1952, or the European Atomic Energy Community (EAEC or Euratom), in 1957. In 1973, the OPEC's power takeover on oil markets found its match within consuming countries, through the creation of the International Energy Agency (IEA) and the establishment of mandatory strategic petroleum reserves.

Since the 1970s, questions regarding the access to and the reliance on natural resources have also been structuring elements for the establishment of energy policies in different importing countries, especially Europe and the United States of America (USA). At the European level, as well as at the French one, energy security constitutes one of the main objectives of the energy policy. This concept has been subject to a new revival during the last decade even if its definition can appear vague. IEA ${ }^{6}$ defines energy security as "the uninterrupted availability of energy sources at an affordable price. Energy security has many aspects: long-term energy

\footnotetext{
${ }^{4}$ Standard Oil of New Jersey, Anglo-Iranian and Royal Dutch Shell signed, on September $17^{\text {th }} 1928$, the Achnacarry agreement, which openly stipulates an equal division of markets and production information, as well as new modalities determining prices. This agreement, considered to be the official birth certificate of the Seven Sisters, was then signed by Mobil Oil, the Standard Oil of California, Gulf Oil, Texaco and later by the Standard Oil of New York, Gulf Oil, Texaco and the Compagnie française des pétroles (CFP). Its main objective was to discipline the different key market actors and avoid any price rivalry.

${ }^{5}$ Saudi Arabia and Norway make interesting examples when it comes to their disproportionate positioning with regards to their demographic or economic weight, through the sole presence of oil resources on their territory.

${ }^{6}$ IEA website: http://www.iea.org/topics/energysecurity/
} 
security mainly deals with timely investments to supply energy in line with economic developments and environmental needs. On the other hand, short-term energy security focuses on the ability of the energy system to react promptly to sudden changes in the supply-demand balance."

By a simple logic of supply in terms of volume, the energy security policies progressively revealed their multiform nature, i.e. a necessary evolution depending on time, space and market conditions. Chester (2010) defines energy security as a polysemic concept considering that it contains various dimensions at the same time that also depends and evolves according to the economic paradigms observed in the energy markets.

Today, the distinguishing features of these energy policies are made up of four main components $^{7}$ described as the $4 \mathrm{~A}^{\prime} \mathrm{s}$ : availability $^{8}$, accessibility $^{9}$, affordability $^{10}$ and acceptability $^{11}$. However some authors (Cherp and Jewell, 2011, 2014) considered that these four factors do not address security questions and need to be completed. Hughes (2009) introduced the four " $R$ ' $s$ " concept. In order to clarify the energy security concept, he explains that a new methodology should be introduced based on "review (understanding the problem), reduce (using less energy), replace (shifting to secure sources), and restrict (limiting new demand to secure sources)".

For the past two decades, a strong interest has emerged in favor of the integration of renewable energies in the energy and electric mix in order to ensure security within the framework of energy transition policies, but also in order to fight against climate change. Implementing these renewable energies is all the more relevant because they allow the state to earn double dividends, as their diffusion de facto reduces the volume of imported fossil

\footnotetext{
${ }^{7}$ This is in reference to the four As policy. For further reference, see Asia Pacific Energy Research Centre, $A$ Quest for Energy Security in the 21st century, Tokyo, August 2007. For more academic reading on the topic, see Jessica Jewell, Aleh Cherp et Keywan Riahi, «Energy security under de-carbonization scenarios: An assessment framework and evaluation under different technology and policy choices », Energy Policy, vol. 65, February 2014, pp. 743-760.

${ }^{8}$ Here, « availability » refers to crude availability, i.e. an observable excess on the market.

${ }^{9}$ A resource may be available but not accessible for several reasons: the absence of commercial relations, contractual divergences, or intestate conflicts. Accessibility somewhat measures the time it takes to access a resource.

${ }^{10}$ This notion comprises a significant economic dimension, i.e. the relation between the resource's cost and the buyer's revenue (or their short-term capacity to pay for the resource).

${ }^{11}$ The notion of acceptability refers to the environmental questions and how they will be received by the local population. At a more global scale, it integrates questions of environmental sustainability.
} 
energy $^{12}$. For instance, in France, the 2015 law on energy transition imposes a 30\% diminution objective in the consumption of fossil energy, which would in turn reduce by about $30 \%$ the country's energy dependence (given that France imports $99.9 \%$ of its fossil energy), induce a decrease in commercial deficit (and thus, of their financing) and could disrupt certain geopolitical balances or relationships with other importing countries.

In 2014, renewable energies represented roughly $23 \%$ of the world's electric production $27.7 \%$ of the electric production capacity - and close to $59 \%$ of the newly set up capacities. This evolution is occurring in an environment where their promotion goes through the affirmation that the geopolitical tensions associated to their development will decrease. Thus, the transition to a consumption of renewable energies would bring about less, if any, conflicts or rivalries linked to the use of resources. The geopolitics of renewable energies, and of energy transition in general, would therefore be "softer" and less conflictual than that of carbonated energy sources. But the new challenges generated by energy transition policies could, paradoxically, reveal themselves to be just as complex as the current energy geopolitics. Hence, there is a risk of tensions in those new relations, which will be more local and less centralized, being created on top of the traditional actors (producers, consumers). It would be equally tempting to conclude that a transition towards renewable energies will progressively put an end to fossil energy geopolitics. Yet, instead of just disappearing, it seems more likely that it will shift interstate relations. Finally, the massive diffusion of renewable energies in the global energy mix could also generate new dependences.

\section{1- Defining the energy transition concept}

The notion of energy transition is rather imprecise. Transitioning from a finite energy source model to a flow energy source model, decarbonizing the energy mix... in reality, the simplest definition seems to be the following: the progressive replacement of the main primary source of energy consumption (US Department of Energy, Energy in Brief, 2001). This definition is especially useful to integrate energy transition within a historical framework. Humanity has known numerous energy transitions, including the use of fire, the manufacturing of tools and handles, wind domestication (mills), water domestication (mills and reservoirs), and, eventually, the discovery of fossil energies. Each has progressively transformed the global

\footnotetext{
${ }^{12}$ Patrick Criqui et Silvana Mima, «European climate-energy security nexus: A model based scenario analysis », Energy Policy, vol. 41, February 2012, pp. 827-842.
} 
economic and energy environment. In the USA, more than thirty-five years were necessary for coal to replace wood in the energy mix (1885) and practically a century for oil to become the main consumed energy source (1950) (Figure 1).

Figure 1 : Energy consumption in the United States

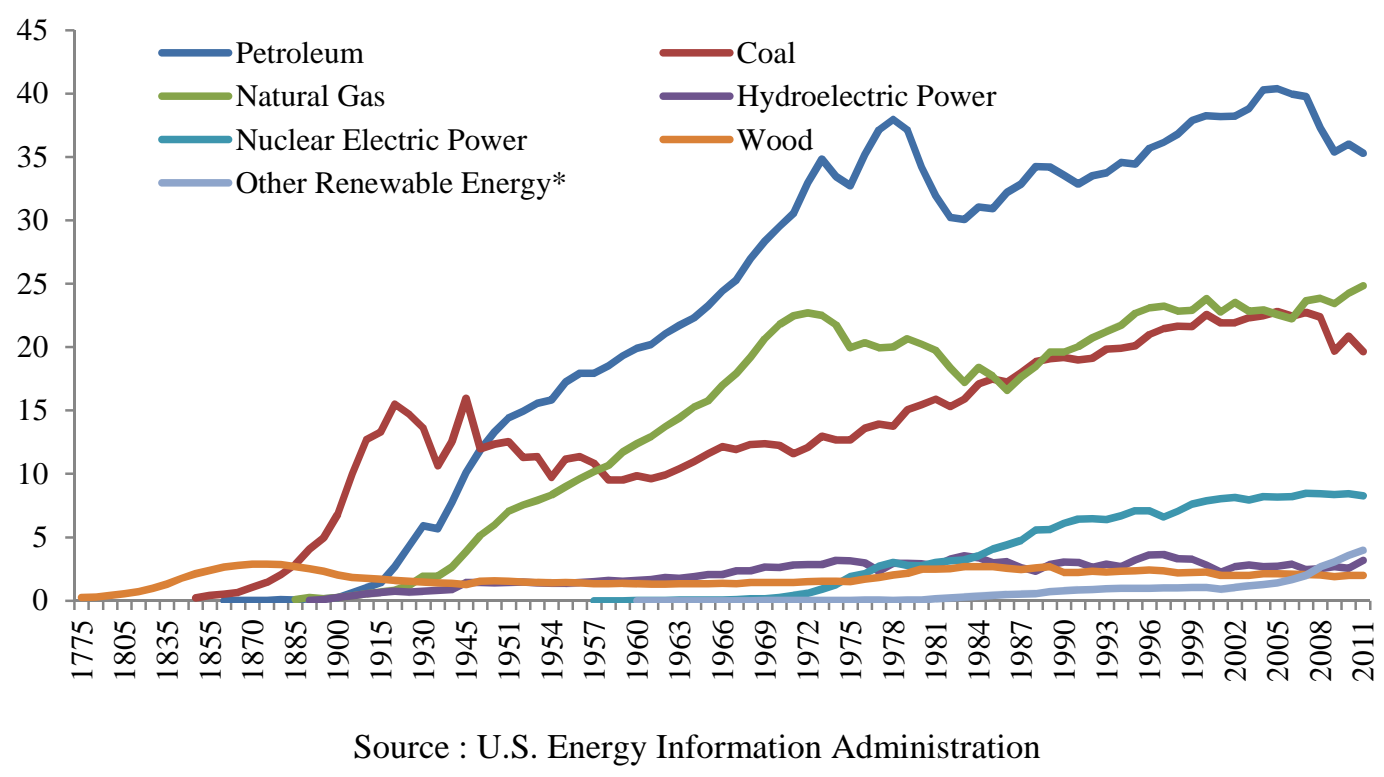

At the present time, the primary energy consumption in the world remains dominated by fossil energy sources (87\%, of which $32.9 \%$ for oil, $29.2 \%$ for coal and $23.8 \%$ for gas), with the hydraulic $(6.8 \%)$, the nuclear $(4.4 \%)$, and other renewable energies $(2.7 \%)$ completing the global landscape (BP Statistical Review, 2016). In this regard, the French energy mix is quite distant from the global energy mix, with the nuclear representing $41 \%$ of its primary energy consumption, oil $34 \%$, gas $15 \%$, coal and hydraulic only $2 \%$, and other renewables $2 \%$ (Ministry of Ecology, Sustainable and Energy Development, 2015 key numbers). In Germany, in 2013, energy consumption was divided between oil (32.4\%), coal (25.7\%), gas (23\%), renewable energies (11.5\%) and nuclear energy (8\%) (Eurostat data, 2015). 


\section{Figure 2 : World Primary Energy : consumption by fuel}

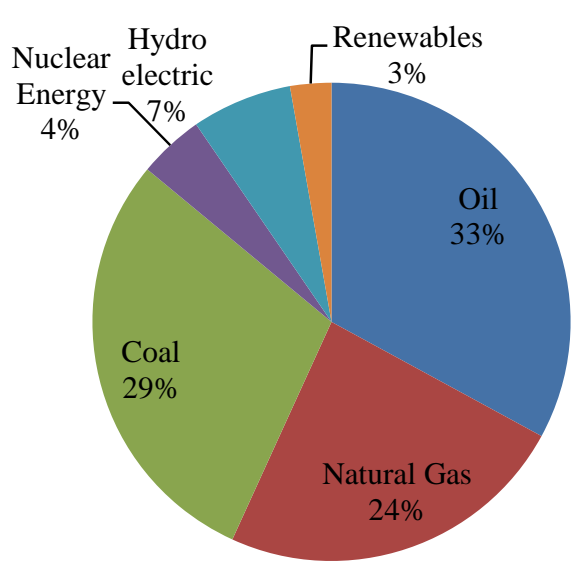

Source : BP Statistical Review, 2016

All these elements might establish a new line of approach on the link between the massive diffusion of renewable energies and energy security. On the one hand, it is necessary to understand that energy transition is a long process, especially because existing energy systems are inert and historical. The consequences of energy policies thus need to be evaluated in the long term. On the other hand, it is important to ensure temporal coherence between all the elements of these policies. Finally, these energy policies integrate a national dimension which needs to be accounted for, given that each mix reflects a temporal, technical and economic construction based on the constraints and preferences of national policy makers.

\section{2- A complex relationship with energy security}

In France, the law on energy transition covers three main goals: fighting against climate change $^{13}$, mastering the demand for energy and the research for energy efficiency ${ }^{14}$, diversifying provision supplies and reaching energy independence ${ }^{15}$. While those simultaneous goals will generate double dividends for environment and security, the massive diffusion of renewable energies forces one to rethink the relationships between producers, consumers, and transit countries. Indeed, renewable energies, unlike fossil energies, are not finite, and their geographic concentration is rather low. Moreover, they bring an important degree of diversification to energy systems. A contrario, their dependence on energy flows

\footnotetext{
${ }^{13}$ Reducing greenhouse gas effects by $40 \%$ between 1990 and 2030, and divide them by four between 1990 and 2050.

${ }^{14}$ Reducing the final consumed energy by $50 \%$ by 2050 (as compared to 2012), while targeting an intermediary goal of $20 \%$ in 2030.

${ }^{15}$ A $30 \%$ reduction in the primary energy consumption of fossil energies by 2030, against a 2012 reference and an increase in the share of renewable energies at $23 \%$ in the crude final energy consumption in 2020 and at $32 \%$ in 2030 .
} 
(wind, sunshine), the poor development of efficient storage techniques and the exacerbated rivalry with terrestrial resources, especially for their installation ${ }^{16}$, generates other dependences.

In national energy transition scenarios, the question of the development of renewable energies invites reflection regarding new territory geopolitics. Indeed, in numerous cases, the envisaged solutions rely on decentralized energy systems, in which case local communities will in large part be responsible of their energy needs. Questions of governance (expertise division between local communities, synergy with other local policies on housing and transportation), of global coherence (investment planning, risk of resources for renewable energies piling up), and of rivalry between different actors (citizens, companies, etc.) will undeniably pop up. In this regard, the example of Germany is interesting to observe: between 2000 and 2012, the renewable energy share in electricity consumption went up from $7 \%$ to $23 \%$, and more than $50 \%$ of the new renewable energy capacities were invested in by citizens (private parties, cooperatives and farmers), against only $7 \%$ by large energy companies (E.ON, EnBW, RWE and Vattenfall). The success in the economic diffusion of renewable energies was the result of the establishment of a triple incentive regime, comprised of judicial, contractual (creation and management of cooperatives) and financial (fiscal advantages and buyback rates in the medium term) frameworks ${ }^{17}$. We could also wonder about the relevance of transposing this model in other European countries, where the markets' oligopolistic structures would render its implementation more difficult.

For scenarios relying on an externalization of electricity production structures ${ }^{18}$, a geopolitical appreciation of renewable energy diffusion requires studying the risks and sensitivity of substituting an actor producing a fossil resource by another producing a transformed resource. Localizing large-scale projects can turn out to be a fundamental question in order to evaluate the impact that the diffusion of renewable energies can have on international geopolitics. Prioritizing the objectives of energy policies for renewable energies will be just as decisive as it is in the absence of renewable energies in the energy mix. These objectives should allow a certain arbitration between the supply of resources at a lower cost and the potential risk of national supply deficits in the case of hostile relations with the capacity-hosting countries.

\footnotetext{
${ }^{16}$ When developing biofuels, the potential impact on food insecurity will also depend on many variables, such as future agricultural yields and a change in consumption habits.

${ }^{17}$ Noémie Poize and Andreas Rüdinger, «Projets citoyens pour la production d'énergie renouvelable : une comparaison France-Allemagne », IDDRI Working Paper, ${ }^{\circ}{ }^{1}$, January 2014.

${ }^{18}$ For instance, the Desertec project studies the establishment of a massive renewable energy diffusion in North Africa, in particular to feed the European grid in electricity.
} 


\section{3- Substituting resource geopolitics with one another: the example of critical materials}

While technology is usually put forward in the dynamics of energy transition, it could also represent an impediment to the massive diffusion of innovations in the medium term. The first identified risk is that of the technology itself, of its cost, of its accessibility, and of its acceptance by the different stakeholders. It is accompanied by a second factor, which is linked to the decentralization and automation of systems, i.e. the risk of cyber-terrorism or of longdistance takeover of electric production units. The third identified risk tends to minimize the impacts involved with reducing geopolitical dependence when introducing renewable energies in the energy mix, i.e. the question of critical or strategic metals.

Found in numerous decarbonization technologies, critical metals are essential to the energy transition, whether it be directly - integration within technologies - or indirectly - component linked but independent of the technology, such as batteries for electric vehicles. Hence, whether it be for the sectors of electric vehicles and plug-in hybrids (cobalt, lanthanum, lithium, etc.), of catalysts or fuel cells (platinum, palladium, rhodium, etc.), the wind-powered (neodymium, dysprosium, terbium, etc.), the civil aeronautical (titanium), or even solar PV (cadmium, indium, gallium, etc.) sectors, all the innovations involved in the decarbonization process rely in fine on the availability of strategic minerals. Yet, the large-scale diffusion of energy transition technologies could exacerbate tensions on these metals' markets, for several reasons.

Most of these markets are rather small in size compared to that of non-ferrous metals ${ }^{19}$; they are unorganized ${ }^{20}$, poorly transparent, and the majority of their transactions are done by mutual agreement. Thus, a "strategic" resource, i.e. essential for the industry but potentially risky in terms of supply, would rapidly risk becoming "critical" in the case of a massive deployment of these technologies. Moreover, the metals used for innovations in the energy transition process are, for the most part, coproducts generated from mining activities. Hence,

\footnotetext{
${ }^{19}$ The markets for non-ferrous metals (copper, aluminum, nickel, etc.) produce in millions of tons, while smaller metals usually produce in tons, hundreds of tons, or, less frequently, in thousands of tons.

${ }^{20}$ Like the London Metal Exchange for the non-ferrous metals there is no global trading platforms and organized market for strategic markets such as lithium, platinum, rhodium...
} 
their extraction and production are geologically and economically reliant on other metals ${ }^{21}$. In this context, supply elasticity according to price movement remains low, which doesn't help in reducing tensions in the short term.

Let us also be reminded that there are very close links between metal production and energy production. Both sectors are intimately tied, given that not only is around $8 \%$ to $10 \%$ of the world's primary energy used to extract and refine metallic resources, but the mining industry itself represents $20 \%$ of the energy used across the industrial sector at a global scale. Any increase in the global metal demand will induce an increase in the energy demand. In this context, the question of the sensitivity of renewable energies - in terms of energy or metal consumption - is bound to be asked. Finally, resource localization and actors' strategy (industrial structures, embargo policies, etc.) can render critical the use of raw materials. Lithium, a strategic metal for the production of batteries, is quite representative of what is now at stake in the process of energy transition : the electrification potential of vehicles at a global scale, the concentration of reserves and production within a small number of countries $^{22}$ compared to crude oil for example (Figure 3, Figure 4), and the market's oligopolistic structure might give countries' material reliance a new face (Figure 5).

\section{Figure 3 : Oil reserves by country (left figure), lithium reserves by country (right figure)}
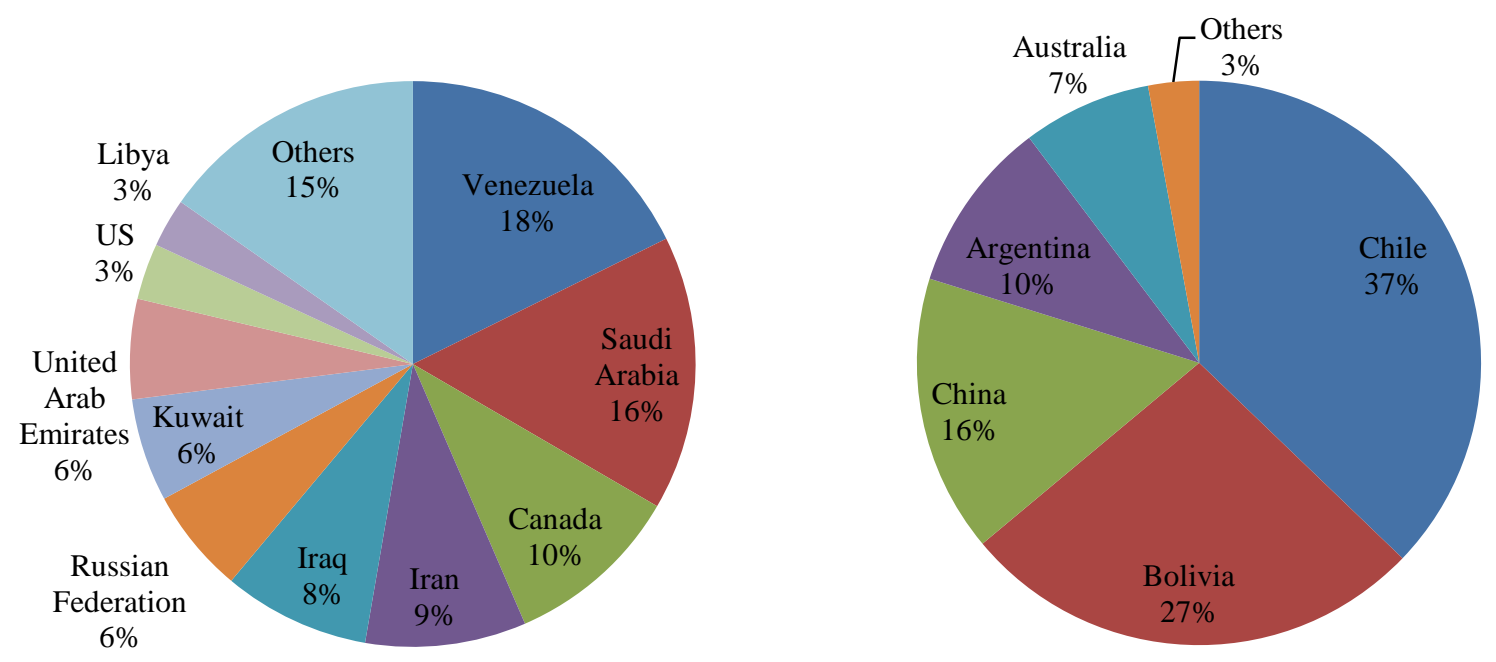

Sources : BP Statistical review, 2016; USGS; countries information

\footnotetext{
${ }^{21}$ Given that critical metals exist in low quantities, it is not economically viable to extract them as main products, but rather as coproducts or byproducts of a major metal - or yet, as byproducts of other byproducts. For instance, gallium and vanadium are aluminum byproducts. Rhenium is a molybdenum byproduct, which is itself a copper coproduct.

${ }^{22}$ Argentina, Bolivia and Chile form what is called the lithium triangle.
} 
Figure 4 : Oil production by country (left figure), lithium production by country (right figure)
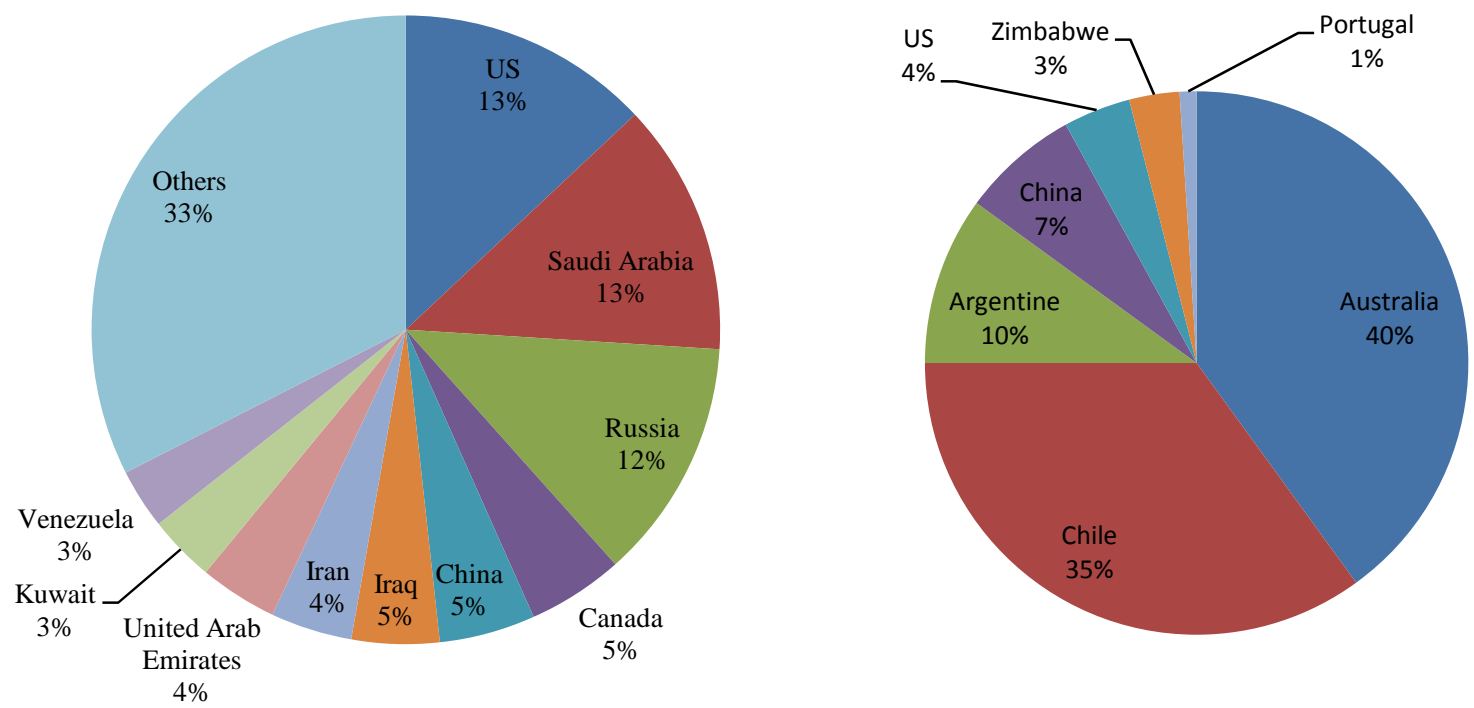

Sources : BP Statistical review, 2016; USGS; countries information

Figure 5 : Lithium market : sales by company in 2014

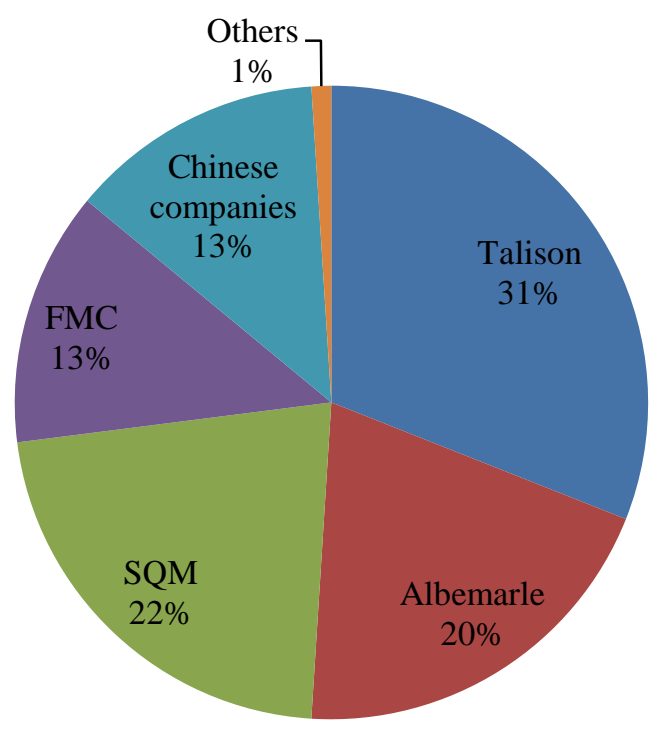

Source : Albemarle (2015)

\section{4- A new geopolitics of patents}

In parallel to criticality, the question of industrial property rights is essential in order to understand the evolution of energy politics, and especially that of renewable energies. Indeed, 
the industrial property of the most reliable technologies in the decarbonization sector will necessarily influence their diffusion cost. The four technological decarbonization families (biofuels, wind-powered, solar PV and solar thermal) were at the receiving end of a 280 billion dollar investment in 2014, close to the number recorded in 2011, with solar power remaining the most promising field at the moment and wind-powered the most mature. The World Intellectual Property Organization (WIPO) ${ }^{23}$ thus compared, in 2014, the number of patents filed for these four categories between 2006 and 2011: over this period, their volume surpassed the one registered between 1975 and 2005 (Table 1). Moreover, their recent annual growth rate exceeded the one observed for patents filed across all technology sectors between $13 \%$ and $27 \%$ for these four technological families, against $6 \%$ globally.

\section{Figure 6 : New Investment in Renewable energy by region in 2015 (in billion \$)}

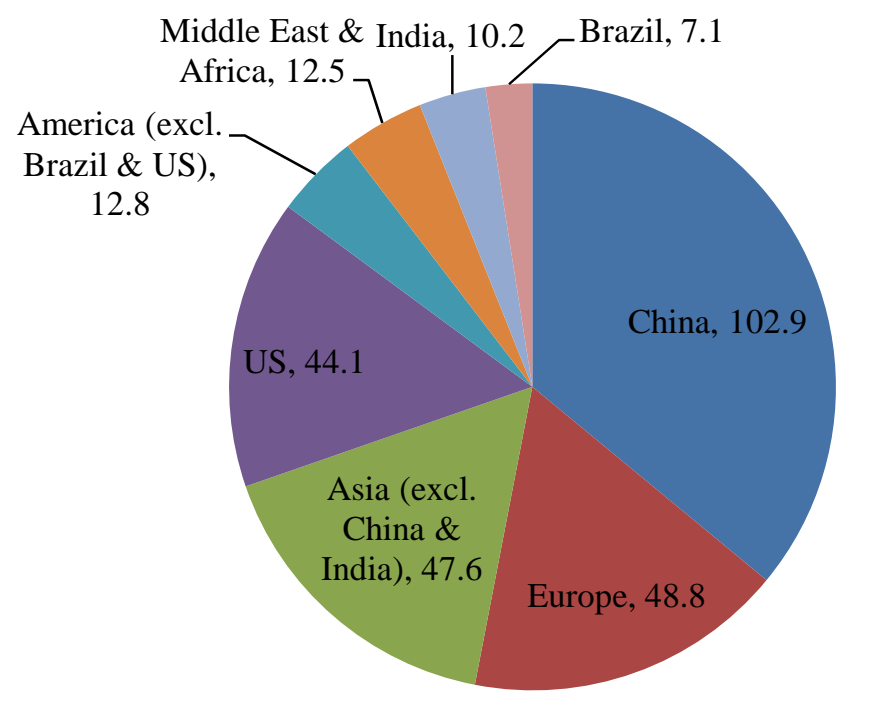

Source : UNEP, Bloomberg New energy Finance

A geographic analysis allows a better understanding of the future global energy geopolitical outlines: in 2014, China represented around a third of the investments in renewable energies (Figure 6), of which $25 \%$ in solar power, followed by Europe and the USA. In terms of patents, China is also ahead for three of the four renewable energy technological families, having filed $55 \%$ of the solar thermal energy patents and $25 \%$ of the biofuel patents. Between 1975 and 2005, four countries in particular carried the patent dynamic for renewable energies: South Korea (LG), Japan through its Keiretsu (conglomerates, such as Mitsubishi, Panasonic, Sharp, etc.), Germany (Siemens) and the United States (General Electric). The 2000s recorded

\footnotetext{
${ }^{23}$ Launch of world intellectual property indicators, December 2014.
} 
China's sensational debut on numerous segments of renewable energy technologies. Hence, in the biofuel sector, China appears alongside Japan as an innovative pole. Indeed, 11 companies or institutions out of the 20 new incomers in the ranking since 2006 are localized on Chinese territory (Sinopec, Nanjing University, etc.). In the solar thermal technologies sector, Japan, leader over the 1975-2005 period, is now surpassed by China - close to 57\% of the filed patents between 2006 and 2011 -, who owns close to $50 \%$ of the 20 top global companies in this sector.

Table 1 : Global Patent Filing Rates

\begin{tabular}{|l|c|c|}
\hline Technology classification & $\begin{array}{c}\text { Average annual growth rate } \\
1975-2005\end{array}$ & $\begin{array}{c}\text { Average annual growth rate } \\
2006-2011\end{array}$ \\
\hline Biofuels & $9 \%$ & $13 \%$ \\
Solar Thermal & $3 \%$ & $24 \%$ \\
Solar PV & $10 \%$ & $22 \%$ \\
Wind & $9 \%$ & $27 \%$ \\
Global patent filings & $3 \%$ & $6 \%$ \\
\hline
\end{tabular}

Source : CambridgeIP, 2014

Japan and Germany are the only countries still resisting in a sector where China, with its large inland and its capacity to carry out large scale solar projects, should remain dominant in the following years. It would also be relevant to study the solar PV sector. Indeed, during the early 2000s, the only countries producing panels of this type were the USA, Germany and Japan; since 2010, China manufactures more than half of them. Moreover, China moved upmarket, widely exceeding both in conception and innovation in the traditional silicon-based PV field. This dynamic is further reinforced by the delocalization movement of numerous research and development (R\&D) centers from developed countries to China.

While the link between patent-innovation and innovation-deployment isn't necessarily straightforward or easy to establish ${ }^{24}$, recent developments in these four technological families inform us on the potential weight carried by different countries or zones in terms of power on the technological markets for the years to come. China, a key player in energy geopolitics, could strengthen its role thanks to the rise of renewable energies, but as a supplier of technological solutions.

The patent issue is usually analyzed with a normative finality, in order to create a relevant framework regarding the transfer of decarbonization technology from North countries to

\footnotetext{
${ }^{24}$ Indeed, energy price structuring within countries, the complementarity between private and public R\&D, or the sector's global governance are all sectors which can impede the links between patent, innovation, and largescale technology deployment.
} 
South countries. Yet, a more geopolitical approach would also mean questioning the industry dimension, especially through the search for a financial and economic market power for these technologies. The USA, Asia (China, Japan), and Europe - especially Germany - should remain major $R \& D$ zones for the decarbonization sector, while China should assert its position as a potential future leader. This card redistribution brings forward the question of new forms of cooperation to develop within the great environmental challenges to come. Developing cooperation and drawing win-win agreements for as many countries as possible (whether it be with a balance between private and public R\&D or within a transnational cooperation framework) proves necessary if we are to avoid generating new exacerbated dependences. Not accounting for this dimension when favoring renewable energy policies would only replace a dependence on resources with a dependence on technology.

\section{5- Conclusion : Towards a diplomacy of renewable energies?}

The diffusion of renewable energies in the global energy mix would also affect countries producing fossil resources. On the one hand, it would be legitimate to think that these policies will have profound consequences on fossil energy markets, with oil and coal being the first targeted. This diminution - or rather, slowing down at first - of the import volume would therefore affect producing countries' demand security ${ }^{25}$ and would have large macroeconomic implications for them. The decrease in prices, and thus in export and budgetary revenues in the long term, could ultimately modify the national and regional balance.

On the other hand, this movement would have a significant impact on the economic structures of producing countries and, by contagion effect, on the economic and international financing circuits. Indeed, the diversification movement towards renewable energies, already observable in many producing countries (Saudi Arabia, United Arab Emirates, etc.), could incite them to strongly diminish the extraction rhythm of fossil resources, which would in turn allow them to divide up their revenue in the long term. The regional balance and relative power of states could thus be transformed, contributing to a distinct risk increase in certain geographic zones. Finally, the decrease in oil revenues would have significant consequences on developed countries, especially those, USA being the main one concerned, which benefit from the

\footnotetext{
${ }^{25}$ Demand security is a concept developed by the OPEC, and is meant to be the counterpart to supply security from consuming countries to producing countries. It symbolizes specifically the necessity for producing countries to have a stable and foreseeable trajectory.
} 
recycling of petrodollars for their debt emissions. Hence, by contagion effect, the change in the model of oil producing countries would not be without consequence for the global economy and financial balance. The policies regarding an energy transition towards renewables should not completely iron out traditional energy geopolitics, but rather open a new chapter in international relations. While they could decrease the reliance on different fossil energy producers and allow the energy mix to be less carbonated, they are not exempt of generating new dependences themselves. Indeed, a dependence on resources such as fossil energy could be replaced with a dependence on other resources, such as strategic metals, to which a major technological component would add up (patents), especially for the diffusion of the most efficient decarbonization technologies in countries in the global South. For this reason, the question of international cooperation is thus fundamental and will also forge the geopolitics of renewables. In line with the COP 21, it seems necessary for this to happen quickly in order to pave the way for a new energy world order. With the diffusion of renewable energies, global energy geopolitics will undeniably become more complex.

\section{Bibliography}

BP Statistical Review of World Energy 2016. [Online] http://www.bp.com/en/global/corporate/energy-economics/statistical-review-of-worldenergy.html

CambridgeIP, 2014. The acceleration of climate change and mitigation technologies: Intellectual property trends in the renewable energy landscape. Global Challenges Brief, WIPO: Geneva. [Online] www.wipo.int/globalchallenges

Cherp, A; Jewell, J. (2011). The three perspectives on energy security: intellectual history, disciplinary roots and the potential for integration. Current Opinion in Environmental Sustainability, 3, 202-212.

Cherp, A; Jewell, J. (2014). The concept of energy security: Beyond the four As. Energy Policy 75, 415-421.

Chester, L., (2010), "Conceptualising energy security and making explicit its polysemic nature", Energy Policy 38, 887-895.

Criqui, P., Mima, S. (2012). European climate-energy security nexus: A model based scenario analysis. Energy Policy, Volume 4, 827-841.

Eurostat Data (2015). [Online] http://ec.europa.eu/eurostat/web/energy/data/database

French Ministry of Ecology, Sustainable and Energy Development, (2015) key numbers.

Hache, E., (2016), "La géopolitique des énergies renouvelables : amélioration de la sécurité énergétique et / ou nouvelles dépendances ?", Revue Internationale et Stratégique, $\mathrm{n}^{\circ} 101$. 
Hughes, L. (2009). The Four 'R's of energy security. Energy Policy 37, 2459-2461.

Jewell, J., Cherp, A., Riahi, K., (2014). Energy security under de-carbonization scenarios: An assessment framework and evaluation under different technology and policy choices, Energy Policy, vol. 65, pp. 743-760.

Poize, N., Rüdinger, A. (2014). Projets citoyens pour la production d'énergie renouvelable : une comparaison France-Allemagne, IDDRI Working Paper, $\mathrm{n}^{\circ} 1$.

US Department of Energy, (2001). Energy in Brief.

WIPO, 2014. US and China Drive International Patent Filing Growth in Record-Setting Year. [Online] http://www.wipo.int/pressroom/en/articles/2014/article_0002.html 


\section{The "Cahiers de I'Économie" Series}

The "Cahiers de l'économie" Series of occasional discussion papers was launched in 1990 with the aim to enable scholars, researchers and practitioners to share important ideas with a broad audience of stakeholders including, academics, government departments, regulators, policy organisations and energy companies.

All these discussion papers are available upon request at IFP School. Discussion papers from 2004 onwards can be downloaded at: www.ifpen.fr

The list of discussion papers from 2006 onwards includes:

\section{\# 59. F. LESCAROUX}

The Economic Consequences of Rising Oil Prices. May 2006

\section{\# 60. F. LESCAROUX, O. RECH}

L'origine des disparités de demande de carburant dans l'espace et le temps : l'effet de la saturation de l'équipement en automobiles sur l'élasticité revenu.

June 2006

\section{\# 61. C. I. VASQUEZ JOSSE, A. NEUMANN}

Transatlantic Natural Gas Price and Oil Price Relationships - An

Empirical Analysis.

September 2006

\section{\# 62. E. HACHE}

Une analyse de la stratégie des compagnies pétrolières internationales entre 1999 et 2004.

July 2006

\section{\# 63. F. BERNARD, A. PRIEUR}

Biofuel market and carbon modelling to evaluate French

biofuel policy.

October 2006

\section{\# 64. E. HACHE}

Que font les compagnies pétrolières internationales de leurs profits?

January 2007

\section{\# 65. A. PIERRU}

A note on the valuation of subsidized Loans

January 2007

\section{\# 66. D. BABUSIAUX, P. R. BAUQUIS}

Depletion of Petroleum Reserves and Oil Price trends September 2007

\section{\# 67. F. LESCAROUX}

Car ownership in relation to income distribution and consumers's spending decisions.

November 2007

\section{\# 68. D. BABUSIAUX, A. PIERRU}

Short-run and long-run marginal costs of joint products in linear programming

June 2008

\section{\# 69. E. HACHE}

Commodities Markets: New paradigm or new fashion? July 2008

\section{\# 70. D. BABUSIAUX, A. PIERRU}

Investment project valuation: A new equity perspective February 2009

\section{\# 71. O. MASSOL, S. TCHUNG-MING}

Stratégies coopératives dans l'industrie du GNL : l'argument de la rationalisation est-il fondé ?

February 2009

\# 72. A. PIERRU, D.BABUSIAUX

Valuation of investment projects by an international oil company A new proof of a straightforward, rigorous method
February 2009

\section{\# 73. E. SENTENAC CHEMIN}

Is the price effect on fuel consumption symmetric? Some evidence from an empirical study April 2009

\section{\# 74. E. HACHE}

OBAMA : Vers un green New Deal énergétique? September 2009

\section{\# 75. O. MASSOL}

Cost function for the natural gas transmission industry: further considerations

September 2009

\section{\# 76. F. LANTZ, E. SENTENAC CHEMIN}

Analyse des tendances et des ruptures sur le marché automobile français. Modélisation du taux de diésélisation dans le parc December 2010.

\section{\# 77. B. CHÈZE, P. GASTINEAU, J. CHEV ALLIER}

Forecasting air traffic and corresponding Jet-Fuel Demand until 2025

December 2010.

\# 78. V. BREMOND, E. HACHE, V. MIGNON

Does OPEC still exist as a cartel? An empirical investigation March 2011

\section{\# 79. I. ABADA, O. MASSOL}

Security of supply and retail competition in the European gas market. Some model-based insights. March 2011

\# 80. E. HACHE, F. LANTZ

Oil price volatility: an econometric analysis of the WTI market. April 2011.

\section{\# 81. I. ABADA, V. BRIAT, O. MASSOL}

Construction of a fuel demand function portraying interfuel substitution, a system dynamics approach. April 2011

\section{\# 82 E. LE CADRE, F. LANTZ, P-A. JOUVET}

The bioenergies development: the role of biofuels and the $\mathrm{CO} 2$ price.

December 2011

\section{\# 83. E. LE CADRE, F. LANTZ, A. FARNOOSH}

Bioenergies usages in electricity generation utility means through a modelling approach: application to the French case. December 201

\# 84. I. ABADA, V. BRIAT, S. GABRIEL, O. MASSOL A generalized Nash-Cournot model for the north-western European natural gas markets with a fuel substitution demand function: the GaMMES model. December 2011

\section{\# 85. O. MASSOL, A. BANAL-ESTAÑOL}

Export diversification and resource-based industrialization: the case of natural gas.

December 2011 
\# 86. B. CHÈZE, P. GASTINEAU, J. CHEV ALLIER

Air traffic energy efficiency differs from place to place: analysis of historical trends by geographical zones using a macro-level

methodology.

December 2011

\section{\# 87. D. LORNE, S. TCHUNG-MING}

The French biofuels mandates under cost uncertainty - an assessment based on robust optimization.

September 2012

\section{\# 88. L. de MAACK, F. LANTZ}

Petroleum products price interactions on the world markets: an econometric analysis.

September 2012

\section{\# 89. O. MASSOL, S. TCHUNG-MING}

Joining the CCS Club! Insights from a Northwest European $\mathrm{CO}_{2}$

Pipeline Project.

October 2012

\section{\# 90. F.M. MENTEN, S. TCHUNG-MING, D. LORNE, F. BOUVART}

Lessons from the use of a long-term energy model for consequential life cycle assessment: the BTL case. November 2013

\section{\# 91. A. CHEVALIER, F. LANTZ}

Personal car or shared car? Predicting potential modal shifts from multinomial logit models and bootstrap confidence intervals November 2013

\section{\# 92. A. FARNOOSH, F. LANTZ, J. PERCEBOIS}

Electricity generation analyses in an oil-exporting country:

Transition to non-fossil fuel based power units in Saudi Arabia December 2013

\section{\# 93. V. BREMOND, E. HACHE, M. JOËTS}

On the link between oil and commodity prices: a panel VAR

approach.

December 2013

\# 94. B. CHÈZE, J. CHEVALLIER, P. GASTINEAU

Will technological progress be sufficient to stabilize $\mathrm{CO}_{2}$ emissions from air transport in the mid-term?

December 2013

\# 95. F. MENTEN, B. CHÈZE, L. PATOUILLARD, F. BOUVART The use of Meta-Regression Analysis to harmonize LCA literature: an application to GHG emissions of $2^{\text {nd }}$ and $3^{\text {rd }}$ generation biofuels December 2013

\section{\# 96. A. DIAZ, S. PROOST}

Second-best urban tolling with distributive concerns.

December 2013

\# 97. O. MASSOL, A. BANAL-ESTAÑOL

Market power across the Channel: Are Continental European gas markets isolated?

January 2014

\# 98. C. NICOLAS, V. SAINT-ANTONIN, S. TCHUNG-MING

(How) does sectoral detail affect the robustness of policy insights from energy system models? The refining sector's example October 2014

\# 99. V. BREMOND, E. HACHE, T. RAZAFINDRABE

On the link between oil price and exchange rate:

A time-varying VAR parameter approach.

July 2015

\# 100. A. BANAL-ESTAÑOL, J. ECKHAUSE, O. MASSOL Incentives for early adoption of carbon capture technology: further considerations from a European perspective. July 2015

\section{\# 101. A. FARNOOSH, F. LANTZ}

Decarbonisation of electricity generation in an oil \& gas producing country: "A sensitivity analysis over the power sector in Egypt" July 2015
* 102 F. FOSSE, E. HACHE, P. PORTENART

Un nouveau cycle de fusions et acquisitions dans le secteur des hydrocarbures ? Une analyse économique et historique de la période 2008-2015 April 2016

\# 103. E. HACHE, D. LEBOULLENGER, V. MIGNON

Beyond average energy consumption in the French residential housing market: A household classification approach April 2016

\section{\# 104. A. PARIS}

The Effect of Biofuels on the Link between Oil and Agricultural Commodity Prices: A Smooth Transition Cointegration Approach. April 2016

\section{\# 105. A. FARNOOSH}

On the economic optimization of national power generation mix in Iran: A Markowitz' portfolio-based approach. April 2016

\# 106. E. HACHE, O. MASSOL

Sanctions against Iran: An assessment of their global impact through the lens of international methanol prices. April 2016

\# 107. M. DUPOUX

The land use change time-accounting failure. July 2016

\# 108. C. NICOLAS, S. TCHUNG-MING, O. BAHN, E. DELAGE

Robust Energy Transition Pathways for Global Warming Targets September 2016

\# 109. E. HACHE

Do renewable energies improve energy security in the long run? September 2016 